\title{
Secondhand tobacco smoke in public venues in three Indonesian cities
}

\author{
M. Justin Byron, ${ }^{1}$ Dollaris R. Suhadi, ${ }^{2}$ Lisa M. Hepp, ${ }^{3}$ Erika Avila-Tang, ${ }^{1,3,4}$ Jingyan Yang, ${ }^{3}$ Gema Asiani, ${ }^{5}$ Rubaeah, ${ }^{6}$ \\ Stephen A. Tamplin, ${ }^{3}$ Tara S. Bam, ${ }^{7}$ Joanna E. Cohen ${ }^{1,3}$ \\ ${ }^{1}$ Department of Health, Behavior \& Society, Johns Hopkins Bloomberg School of Public Health, Baltimore, Maryland, USA \\ ${ }^{2}$ Swisscontact Indonesia Foundation, Jakarta, Indonesia \\ ${ }^{3}$ Institute for Global Tobacco Control, Johns Hopkins Bloomberg School of Public Health, Baltimore, Maryland, USA \\ ${ }^{4}$ Department of Epidemiology, Johns Hopkins Bloomberg School of Public Health, Baltimore, Maryland, USA \\ ${ }^{5}$ Palembang City Health Agency, Palembang, Indonesia \\ ${ }^{6}$ Bogor City Health Department, Bogor, Indonesia \\ ${ }^{7}$ International Union Against Tuberculosis and Lung Disease, Jakarta, Indonesia
}

\begin{abstract}
Abstrak
Latar belakang: Penelitian ini bertujuan untuk mengukur konsentrasi paparan asap rokok pada tempat-tempat umum di Jakarta, Bogor, dan Palembang sebelum aturan pelarangan merokok di tempat umum diberlakukan.

Metode: Dilakukan pengukuran kandungan partikel (PM..5) pada 15 rumah sakit, 15 instansi pemerintah, 30 restoran, dan 26 tempat hiburan yang berlokasi di ketiga kota tersebut di atas. Di Jakarta, dilakukan juga pengukuran terhadap kandungan fase uap nikotin pada 5 sekolah, 5 rumah sakit, 5 instansi pemerintah, 9 restoran, dan 10 tempat hiburan. Analisa data dilakukan secara deskriptif. Perbedaan karakteristik tempat dianalisis dengan menggunakan Student's t-test, uji ANOVA, dan Bonferroni pairwise statistical tests.

Hasil: Rata-rata geometris tingkat $P M_{2.5}$ ditemukan tertinggi pada tempat hiburan $\left(96 \mu \mathrm{g} / \mathrm{m}^{3}\right)$, disusul restoran $\left(78 \mu \mathrm{g} / \mathrm{m}^{3}\right)$, instansi pemerintahan $\left(57 \mu \mathrm{g} / \mathrm{m}^{3}\right)$, dan rumah sakit $\left(46 \mu \mathrm{g} / \mathrm{m}^{3}\right)$. Tingkat udara dengan kandungan nikotin di Jakarta ditemukan tertinggi pada area khusus merokok $\left(4,71 \mu \mathrm{g} / \mathrm{m}^{3}\right)$ dan area dilarang merokok $\left(1,55 \mu \mathrm{g} / \mathrm{m}^{3}\right)$ yang terdapat di tempat hiburan. Diikuti oleh instansi pemerintahan $\left(0,30 \mu \mathrm{g} / \mathrm{m}^{3}\right)$, area khusus merokok $\left(0,24 \mu \mathrm{g} / \mathrm{m}^{3}\right)$, dan area dilarang merokok $\left(0,19 \mu \mathrm{g} / \mathrm{m}^{3}\right)$ pada restoran, rumah sakit $\left(0,01 \mu \mathrm{g} / \mathrm{m}^{3}\right)$, dan sekolah $\left(0,01 \mu \mathrm{g} / \mathrm{m}^{3}\right)$.
\end{abstract}

Kesimpulan: Paparan asap rokok terdeteksi pada seluruh tempat di tiga kota di Indonesia. Kandungan udara yang mengandung nikotin pada tingkat yang tinggi ditemukan pada area dilarang merokok pada restoran dan tempat hiburan. Hal ini mengindikasikan bahwa dipisahkannya area merokok dan area tidak merokok bukanlah solusi efektif untuk menghilangkan asap rokok. Tidak ada tingkat aman untuk paparan asap rokok, sehingga adanya paparan asap rokok di tempat-tempat tersebut di atas dapat meningkatkan risiko buruk bagi kesehatan anak-anak dan orang dewasa. Temuan ini mendukung perlunya aturan kawasan bebas rokok yang mencakup seluruh tempat umum di ketiga kota tersebut dan seluruh kota di Indonesia. (Med J Indones. 2013;22:232-7. doi: 10.13181/mji.v22i4.606)

\begin{abstract}
Background: The aim of this study was to measure secondhand tobacco (including kretek) smoke (SHS) concentrations in public places in Jakarta, Bogor, and Palembang before laws banning smoking in public spaces went into effect.

Methods: Particulate matter $\left(\mathrm{PM}_{2.5}\right)$ was measured in 15 hospitals, 15 government offices, 30 restaurants, and 26 entertainment venues throughout the three cities. Also, in Jakarta, vapor-phase nicotine was measured in 5 schools, 5 hospitals, 5 government offices, 9 restaurants, and 10 entertainment venues. Data were analyzed descriptively. Differences by city and venue characteristics were analyzed by Student's t-test, ANOVA, and Bonferroni pairwise statistical tests.

Results: Geometric mean $\mathrm{PM}_{2.5}$ levels were highest in entertainment venues $\left(96 \mu \mathrm{g} / \mathrm{m}^{3}\right)$, followed by restaurants $\left(78 \mu \mathrm{g} / \mathrm{m}^{3}\right)$, government offices $\left(57 \mu \mathrm{g} / \mathrm{m}^{3}\right)$, and hospitals $\left(46 \mu \mathrm{g} / \mathrm{m}^{3}\right)$. Air nicotine levels in Jakarta were highest in designated smoking areas $\left(4.71 \mu \mathrm{g} / \mathrm{m}^{3}\right)$ and designated non-smoking areas $\left(1.55 \mu \mathrm{g} / \mathrm{m}^{3}\right)$ of entertainment venues. These were followed by government offices $\left(0.30 \mu \mathrm{g} / \mathrm{m}^{3}\right)$, designated smoking areas $\left(0.24 \mu \mathrm{g} / \mathrm{m}^{3}\right)$ and designated nonsmoking areas $\left(0.19 \mu \mathrm{g} / \mathrm{m}^{3}\right)$ of restaurants, hospitals $\left(0.01 \mu \mathrm{g} / \mathrm{m}^{3}\right)$, and schools $\left(0.01 \mu \mathrm{g} / \mathrm{m}^{3}\right)$.

Conclusion: SHS was detected in all venues in the three cities in Indonesia. High levels of air nicotine were found in non-smoking areas of restaurants and entertainment venues, indicating that designated smoking areas are not an effective solution to eliminate SHS. There is no safe level of SHS exposure and thus SHS in these venues increases the risk of adverse health effects among children and adults. These findings support the need for $100 \%$ smoke-free laws covering all public venues in these and other Indonesian cities. (Med J Indones. 2013;22:232-7. doi: 10.13181/mji.v22i4.606)
\end{abstract}

Keywords: Cigarettes, kretek, protection, protect, secondhand smoke, smoke-free policy, tobacco

An important component of tobacco control efforts is to protect individuals from secondhand smoke (SHS), the combination of exhaled smoke and smoke emitted from a kretek or cigarette. SHS exposure causes many serious adverse health effects including coronary heart disease and lung cancer among adults; and sudden infant death syndrome, acute and chronic respiratory infections, ear infections, and more severe asthma among children. ${ }^{1}$ The World Health Organization (WHO) has declared that there is no safe level of SHS, and that $100 \%$ smoke- 
free policies are the only fully effective solution. ${ }^{2}$ The WHO's Framework Convention on Tobacco Control (FCTC) encourages countries to protect their citizens by enacting legislation banning smoking in all public places and workplaces and on public transportation. ${ }^{3}$ As of July 2013, 177 countries have ratified the FCTC. ${ }^{4}$

Indonesia is the world's fourth largest consumer of cigarettes, including kretek (clove cigarettes). ${ }^{5}$ Of the country's 238 million residents, $67.0 \%$ of adult men and $2.7 \%$ of adult women are smokers, and of them $56.7 \%$ and $1.8 \%$, respectively, are daily smokers. ${ }^{6}$ Smoking has increased markedly since 1995, when the prevalence was $53.9 \%$ among men and $1.7 \%$ among women. ${ }^{6}$ Smokers start young: among children ages 13$15,41.0 \%$ of boys and $3.5 \%$ of girls are already current smokers. ${ }^{7}$ The vast majority $(92 \%)$ of the cigarettes smoked in Indonesia are kretek, ${ }^{8}$ which tend to have higher tar levels than other cigarettes. ${ }^{9}$ Polls show that more than $92 \%$ of the Indonesian public support smoke-free laws, ${ }^{10}$ but the government's response to the issue has not been optimal. Indonesia has not signed or acceded to the FCTC, and national laws addressing SHS exposure have been incomplete and minimally enforced. In Health Law No. 36/2009, the Indonesian central government required local governments to make health facilities, educational facilities, children's activities areas, places of worship, public transportation, and other public places and workplaces smoke-free, but the law explicitly allows for designated smoking areas in some of these buildings, an approach which fails to properly protect nonsmokers. ${ }^{1}$ Additionally, the law did not state any sanctions for jurisdictions that did not implement the law. Therefore, implementation was slow and inconsistent. In 2005, Jakarta passed Law 2/2005 and Implementing Regulation 75/2005, requiring the above venues and all workplaces and public places to be smoke-free, but this law too allowed for designated smoking areas and achieved only partial compliance. In 2010, Jakarta passed a more strict regulation, 88/2010, which eliminates designated indoor smoking areas and, as of 2012, enforcement was improving. In 2012 a further Implementing Regulation 50/2012 was issued. It defines enforcement procedures and administrative sanction mechanisms. In Bogor, preliminary smoke-free legislation was passed in 2006 and then strengthened in 2009 with Law 12/2009, banning smoking in all workplaces and public places, specifying enforceable fines, and allowing the mayor to set regulations regarding designated smoking areas. The mayor required that designated smoking areas must be outdoor roofless areas far from building entrances and must be approved by the health department. In Palembang, Regulation 7/2009 was passed in 2009, banning smoking in all public places and workplaces with no allowance for designated smoking areas. Both Bogor's and Palembang's smoke-free laws took effect in mid-2010. Jakarta's law took effect in late 2010.

The present study was conducted in Jakarta, Bogor, and Palembang in 2009 while these cities were in the midst of discussions and debates about possible smoking restrictions. The purpose of the study was to provide policymakers with objective measures of SHS levels in these three cities in schools, hospitals, government offices, restaurants, and entertainment venues. These measurements were collected using particulate matter $\left(\mathrm{PM}_{2.5}\right)$ and airborne nicotine monitoring techniques, which have been used in a variety of countries and environments worldwide. ${ }^{11-15}$ This study is among the first to report SHS levels in public places in Indonesia.

\section{METHODS}

\section{Design and data collection}

This cross-sectional study measured SHS levels in three cities in Indonesia using a standardized protocol. Jakarta was chosen as a monitoring site since it is the capital city, and Bogor and Palembang were chosen because they were among the first cities to pass comprehensive smoke-free legislation. Data for this study were collected from August through September 2009, before the new smoke-free laws took effect in 2010. Data collection was preceded by three days of training. $\mathrm{PM}_{2.5}$ levels were measured in each city in a convenience sample of 5 hospitals, 5 government offices, 10 restaurants, and 10 entertainment venues. In Jakarta, airborne nicotine was also measured in these venues and in 5 schools. Sampled rooms in these buildings include lobbies, cafeterias, lounges, offices, restrooms, and hospital patient floors. Field workers also noted room dimensions and the number of people actively smoking in the room at 15 minute intervals. Field workers gained permission from responsible authorities at each site before taking measurements or placing the air nicotine monitors. The study was approved by the Jakarta Environmental Management Board, the City Health Office of Bogor, and the City Health Office of Palembang. According to Johns Hopkins Bloomberg School of Public Health Institutional Review Board guidance, the project did not meet the criteria for "human subjects" research and therefore did not require review. The study was locally facilitated by Swisscontact Indonesia Foundation.

\section{Monitoring methods}

SHS concentrations were estimated using both $\mathrm{PM}_{2.5}$ and airborne nicotine measurement methods. $\mathrm{PM}_{2.5}$ was measured using TSI SidePak AM510 Personal Aerosol Monitors (TSI, Shoreview, Minnesota, USA). These 
Table 1. Number of samples for particulate matter and air nicotine. For air nicotine, the percent of samplers detecting nicotine is noted in parentheses

\begin{tabular}{llcccccc}
\hline & & Hospitals & Government & Restaurants & $\begin{array}{c}\text { Entertainment } \\
\text { venues }\end{array}$ & Schools & Total \\
\hline $\mathrm{PM}_{2.5}$ & Bogor & 10 & 10 & 20 & 17 & - & 57 \\
& Jakarta & 10 & 10 & 17 & 12 & - & 49 \\
& Palembang & 10 & 9 & 13 & 7 & - & 39 \\
\multirow{2}{*}{ Air nicotine } & Jakarta & $26(65 \%)$ & $35(100 \%)$ & $17(88 \%)$ & $20(100 \%)$ & $22(32 \%)$ & $120(78 \%)$ \\
\hline
\end{tabular}

aerosol monitors were fitted with a $2.5 \mu \mathrm{m}$ impactor which allowed for measurement of particulate matter with a mass median aerodynamic diameter of less than or equal to $2.5 \mu \mathrm{m}$. The SidePak monitors were calibrated before use. At each $\mathrm{PM}_{2.5}$ collection point, field workers collected data for 5 minutes outdoors to get a background reading and then for 30 continuous minutes indoors in each of two rooms per venue. In 27 venues only one room was measured. Sampling was done discreetly so that patrons would not change their behavior.

Airborne nicotine measurement was accomplished by using small disposable passive samplers containing a filter treated with sodium bisulfate placed in a $37 \mathrm{~mm}$ sampling cassette with a porous diffusion membrane and support pad. ${ }^{16}$ The samplers have an internal volume between the filter and windscreen of $9.49 \mathrm{~cm}^{3}$ and a flow rate of 0.024 liters per minute. The samplers were placed in the chosen locations for 7 days ( 5 days for schools and government offices). The number of samplers placed in each venue depended on venue type and size. Based on a protocol developed from work in other countries, the samplers were placed in the venues as follows: 5-6 samplers in each of 5 hospitals, 6-8 samplers in each of 5 government buildings, 1-2 samplers in each of 9 restaurants, 2 samplers in each of 10 entertainment venues, and 3-5 samplers in each of 5 schools. Once collected, the samplers were placed in sealed containers and shipped to the Secondhand Smoke Assessment Laboratory at the Johns Hopkins Bloomberg School of Public Health (Baltimore, USA) for analysis. In the laboratory, the nicotine was extracted from the filters and analyzed using gas chromatography with nitrogen-selective detection. ${ }^{16,17}$ The concentration of airborne nicotine was calculated by dividing the amount of collected nicotine (in $\mu \mathrm{g}$ ) by the effective volume of air sampled (in $\mathrm{m}^{3}$ ). Some of the samplers placed in venues were lost or taken, leaving 120 for analysis. An additional 12 duplicate sampling units were used for quality control and 13 blank units were used to determine blank-corrected nicotine concentrations. The limit of detection (LOD) ranged from $0.0042 \mu \mathrm{g} / \mathrm{m}^{3}$ to $0.0064 \mu \mathrm{g} / \mathrm{m}^{3}$ in the different batches of samplers processed. Twenty-six samples had nicotine concentrations below the LOD, and these were assigned a value of one half of the LOD. ${ }^{18}$

\section{Statistical analysis}

$\mathrm{PM}_{2.5}$ data were downloaded from the TSI SidePak AM510 monitors and analyzed using STATA statistical software and Microsoft Excel. Active smoking was defined as the presence of at least one smoker at the 0-, 15-, or 30-minute time points. $\mathrm{PM}_{2.5}$ and air nicotine concentrations were log-normally distributed and geometric means, medians, interquartile ranges, and 95\% confidence intervals were calculated for each city, venue type, and smoking status (active smokers present or no active smokers present). Student's t-test, analysis of variance (ANOVA), and Bonferroni pairwise test were used for statistical analysis.

\section{RESULTS}

\section{Particulate matter in Jakarta, Bogor, and Palembang}

Particulate matter readings were taken in a total of 148 rooms in 86 venues. Indoor geometric mean $\mathrm{PM}_{2.5}$ levels were highest in venues in Jakarta $\left(79 \mu \mathrm{g} / \mathrm{m}^{3}\right)$, followed by Bogor $\left(70 \mu \mathrm{g} / \mathrm{m}^{3}\right)$ and then Palembang $\left(56 \mu \mathrm{g} / \mathrm{m}^{3}\right)$. Among the three cities, the difference between Palembang and Jakarta was highly significant $(\mathrm{p}=0.008)$, whereas other differences were statistically not significant (Jakarta vs Bogor, $\mathrm{p}=0.069$; Palembang vs Bogor, $\mathrm{p}=0.998$ ). Comparing venues, indoor $\mathrm{PM}_{2.5}$ levels were highest in entertainment venues $\left(96 \mu \mathrm{g} / \mathrm{m}^{3}\right)$, followed by restaurants $\left(78 \mu \mathrm{g} / \mathrm{m}^{3}\right)$, and then government offices $\left(57 \mu \mathrm{g} / \mathrm{m}^{3}\right)$ and hospitals $\left(46 \mu \mathrm{g} / \mathrm{m}^{3}\right)$ across all cities. Differences across three venues were not statistically significant between government and entertainment $(p=0.131)$, restaurant and entertainment $(\mathrm{p}=0.998)$, hospital and government $(p=0.998)$, government and restaurant $(p=0.469)$, and between hospital and restaurant $(\mathrm{p}=0.081)$, whereas hospital vs entertainment was statistically significant $(p=0.019)$. These indoor values were also statistically significantly different $(\mathrm{p}=0.01)$ compared with the geometric mean outdoor levels of $\mathrm{PM}_{2.5}\left(55 \mu \mathrm{g} / \mathrm{m}^{3}\right)$. The geometric mean for $\mathrm{PM}_{2.5}$ in all indoor places with active smoking observed $\left(85 \mu \mathrm{g} / \mathrm{m}^{3}\right)$ was higher than that of indoor places where smoking was not observed $\left(53 \mu \mathrm{g} / \mathrm{m}^{3}, \mathrm{p}<0.001\right)$. The overall lowest $\mathrm{PM}_{2.5}$ value, 
$19 \mu \mathrm{g} / \mathrm{m}^{3}$, was found in a hospital in Bogor and the highest value, $1,030 \mu \mathrm{g} / \mathrm{m}^{3}$, was found in a restaurant in Jakarta. Figure 1 shows the geometric mean and 95\% confidence intervals for the $\mathrm{PM}_{2.5}$ levels by venue, city, and active smoking.

\section{Airborne nicotine in Jakarta}

Results show that the highest geometric mean (GM) air nicotine values were in designated smoking areas (DSA, $4.71 \mu \mathrm{g} / \mathrm{m}^{3}$ ) and designated non-smoking areas (DNSA, $1.55 \mu \mathrm{g} / \mathrm{m}^{3}$ ) of entertainment venues. These were followed by government offices $\left(0.30 \mu \mathrm{g} / \mathrm{m}^{3}\right)$, DSA $(0.24$ $\left.\mu \mathrm{g} / \mathrm{m}^{3}\right)$ and DNSA $\left(0.19 \mu \mathrm{g} / \mathrm{m}^{3}\right)$ of restaurants, hospitals $\left(0.01 \mu \mathrm{g} / \mathrm{m}^{3}\right)$, and schools $\left(0.01 \mu \mathrm{g} / \mathrm{m}^{3}\right)$. Using ANOVA, these values were statistically significantly different ( $p<0.001)$. Using the Bonferroni pairwise test across venue types for air nicotine, the statistically significant differences were entertainment-DNSA vs entertainmentDSA $(p=0.007)$, government vs entertainment-DNSA $(\mathrm{p}=0.001)$, hospitals vs entertainment-DNSA $(\mathrm{p}<$ 0.001 ), restaurants-DNSA vs entertainment-DNSA ( $p$ $=0.026)$, schools vs entertainment-DNSA $(p<0.001)$, government vs entertainment-DSA $(\mathrm{p}<0.001)$, hospitals vs entertainment-DSA $(\mathrm{p}<0.001)$, restaurants-DSA vs entertainment-DSA $(\mathrm{p}=0.001)$, restaurants-DNSA vs entertainment-DSA $(\mathrm{p}<0.001)$, schools vs entertainmentDSA $(p<0.001)$. Nicotine was detected in $90 \%$ of the measurements taken in non-smoking areas of restaurants and $100 \%$ of the non-smoking areas of entertainment venues (Figure 2).

\section{DISCUSSION}

This study found high levels of SHS in many indoor venues in these Indonesian cities, as indicated by both $\mathrm{PM}_{2.5}$ and air nicotine measurements. The study results show that SHS is present even in designated non-smoking areas. Thus, having designated smoking and non-smoking areas in a venue does not sufficiently protect public health. Levels of SHS were highest in entertainment venues, followed by restaurants, government offices and hospitals (although the statistical significance of these differences was limited). These findings are consistent with other particulate matter and air nicotine studies in Asia which tend to find the highest levels in bars, entertainment
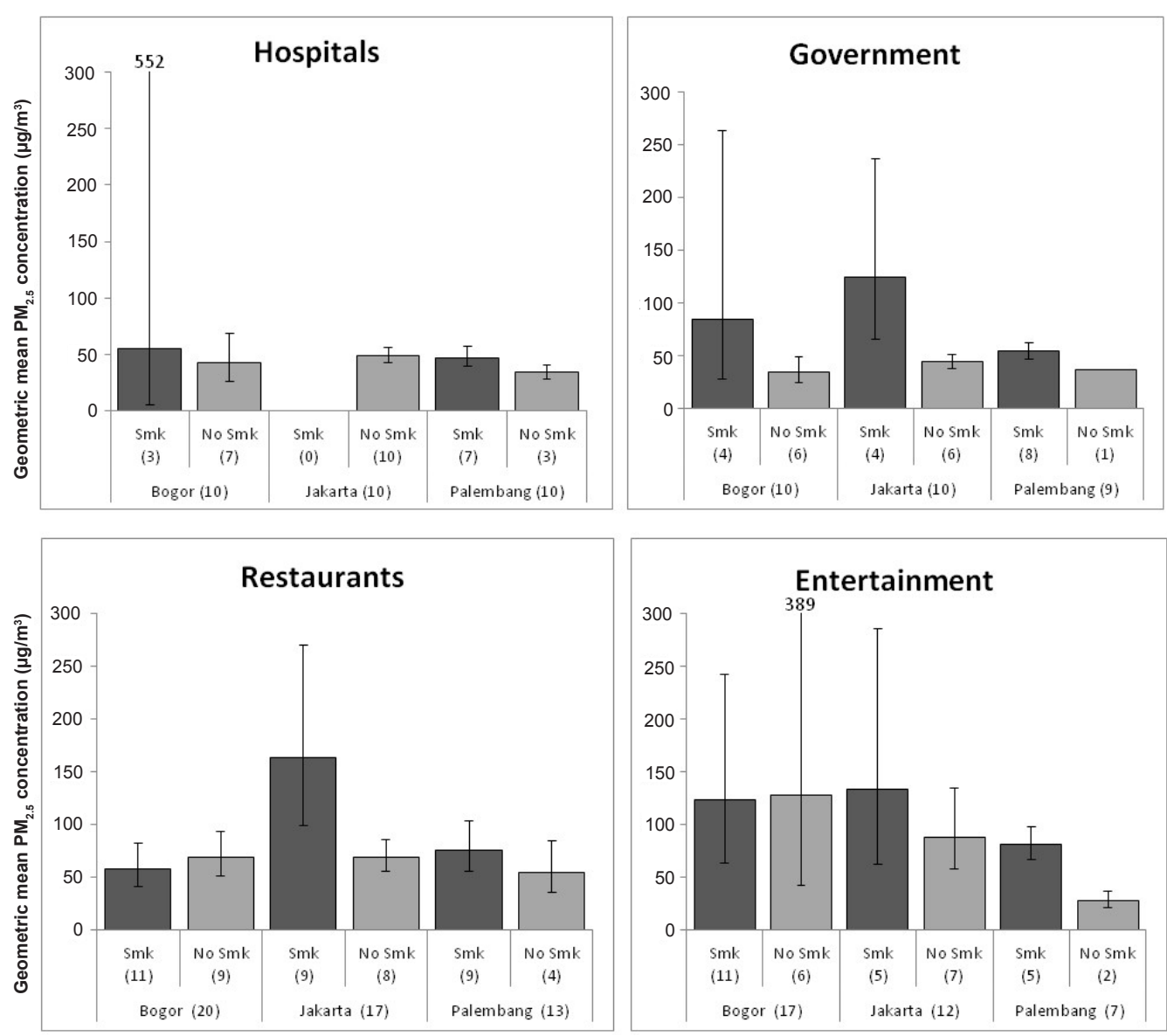

Figure 1. Particulate matter $\left(P M_{2.5}\right)$ levels by venue-type, city, and active smoking. Error bars indicate 95\% confidence intervals. Numbers in parenthases indicate the number of rooms sampled. Smk = area with active smokers, No Smk = area without active smokers 


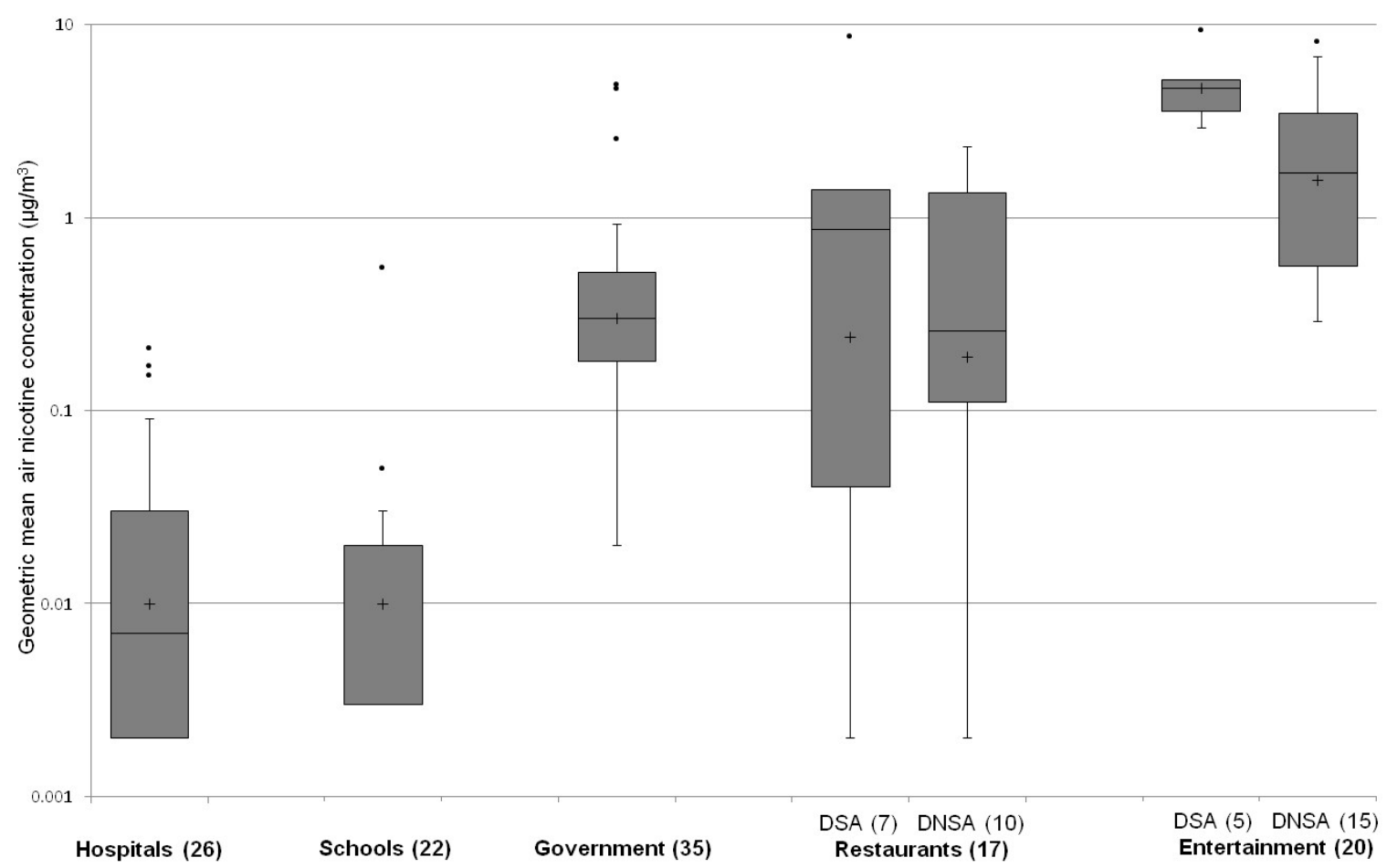

Figure 2. Air nicotine concentrations in Jakarta by venue-type (logarithmic scale). Limit of detection (LOD) for nicotine varied from $0.0042 \mu \mathrm{g} / \mathrm{m}^{3}$ to $0.0064 \mu \mathrm{g} / \mathrm{m}^{3}$ in different samples. Measurements below the LOD were assigned a value of one half of the LOD. "+” indicate the Geometric Mean. DSA = Designated smoking area, DSNA= Designated non-smoking area.

venues, and restaurants, and the lowest levels in schools and hospitals. ${ }^{12,13,19}$ The levels of SHS found in restaurants and entertainment venues in this study were high $\left(\mathrm{PM}_{2.5}\right.$ levels up to $\left.1,030 \mu \mathrm{g} / \mathrm{m}^{3}\right)$. At these levels a person may have more $\mathrm{PM}_{2.5}$ exposure in 40 minutes than is acceptable for an entire day by WHO guidelines. ${ }^{20}$ Based on work exposure ( 8 hours) an employee would probably be exceeding the WHO guideline for $\mathrm{PM}_{2.5}$ (by being exposed to over $\left.75 \mu \mathrm{g} / \mathrm{m}^{3}\right)$ in $45 \%$ (13/29) of the sampled venues in Bogor, 50\% (15/30) of the sampled venues in Jakarta, and 26\% (7/27) of the sampled venues in Palembang. A recent study found geometric mean $\mathrm{PM}_{2.5}$ levels in Southeast Asian and Pacific countries (excluding Indonesia) of $159 \mu \mathrm{g} / \mathrm{m}^{3}$ in indoor areas with active smokers and $22 \mu \mathrm{g} / \mathrm{m}^{3}$ in areas without active smokers. ${ }^{12}$ Comparatively, in Indonesia we found higher $\mathrm{PM}_{2.5}\left(53 \mu \mathrm{g} / \mathrm{m}^{3}\right)$ in areas without active smoking, and lower $\mathrm{PM}_{2.5}$ in areas with active smoking $\left(85 \mu \mathrm{g} / \mathrm{m}^{3}\right)$. The levels of SHS found in hospitals and schools were quite low, indicating that smoke-free policies in these locations have generally been successful. Compliance checks in Bogor in 2013 found the smoke-free law was working well in most places, but there was still a need for strengthened implementation efforts in restaurants, entertainment places, and hotels.

This study is among the first to report SHS measurements in public places in Indonesia. The strengths of the study are that standardized methods were used and air nicotine monitoring was used to support the findings of the particulate matter monitoring (air nicotine is specific to tobacco smoke). This study was limited by its moderate sample size and convenience sampling approach. Therefore, the findings may not be fully representative or generalizable. However, the purpose was not to estimate exposure using a representative sample but to measure SHS levels in a predetermined number of policy-relevant venues. As a second limitation, some measurements in Bogor were made during Ramadan, when Muslims are forbidden to smoke during the day. A third limitation was that the $\mathrm{PM}_{2.5}$ collection method is not specific to tobacco smoke and may include particulate matter from cooking stoves and ambient air pollution. In the air nicotine component of the project, the measurements were made on a continuous basis and therefore likely underestimate smoke concentrations at the time of occupancy.

In conclusion, together with proven techniques of determined leadership, community organizing, and education campaigns, SHS monitoring can be a tool to support smoke-free advocacy efforts. The sharing of preliminary results of this study contributed to the enactment of $100 \%$ smoke-free policy in Jakarta, Bogor, and Palembang. There is a need for more widespread comprehensive $100 \%$ smoke-free laws in Indonesia, without exceptions for designated smoking areas. Air 
monitoring data and compliance checks can be used effectively to make the case for such laws and ensure that they are effective in protecting public health.

\section{Acknowledgments}

This work was supported by an award from the Bloomberg Initiative to Reduce Tobacco Use. We greatly appreciate the assistance of Swisscontact Indonesia Foundation, Jakarta Environmental Management Board, Bogor City Health Office, No Tobacco Community in Bogor, and Palembang City Health Office. Thanks also to the International Union Against Tuberculosis and Lung Disease for technical coordination and organization of the survey.

\section{REFERENCES}

1. US Department of Health and Human Services. The health consequences of involuntary exposure to tobacco smoke: A report of the Surgeon General. Atlanta, GA: US DHHS Centers for Disease Control and Prevention, Office on Smoking and Health; 2006.

2. WHO. Protection from exposure to second-hand tobacco smoke: Policy recommendations. Geneva: World Health Organization; 2007.

3. WHO. WHO Framework Convention on Tobacco Control. Geneva: World Health Organization; 2005 updated reprint.

4. WHO [Internet]. Parties to the WHO Framework Convention on Tobacco Control. 2013 [updated 2013 June 25; cited 2013 July 29]; Available from: http://www.who. int/fctc/signatories parties/en/index.html.

5. Eriksen M, Mackay J, Ross H. The tobacco atlas. 4th ed. New York: World Lung Foundation; 2012.

6. WHO. Global Adult Tobacco Survey: Indonesia report 2011. Geneva: World Health Organization; 2012.

7. WHO. Global Youth Tobacco Survey: Indonesia 2009 factsheet (ages 13-15). Geneva: World Health Organization; 2009.

8. Brinson B. A good match: Sampoerna continues to thrive following its acquisition by Philip Morris. Tobacco Reporter. 2008 Nov:54.
9. Euromonitor. Cigarettes - Indonesia. London: Euromonitor International; 2010.

10. Ministry of Health, Republic of Indonesia. Factsheet No.4. Indonesians strongly support establishment of $100 \%$ smoke-free environments. Ministry of Health, Republic of Indonesia, Directorate General of Disease Control and Environmental Health, Directorate of Non-Communicable Disease Control, 2011.

11. Wipfli HL, Fujimoto K, Valente TW. Global tobacco control diffusion: The case of the Framework Convention on Tobacco Control. Am J Public Health. 2010;100(7):1260-6.

12. Hyland A, Travers MJ, Dresler C, Higbee C, Cummings KM. A 32-country comparison of tobacco smoke derived particle levels in indoor public places. Tob Control. 2008;17(3):159-65.

13. Lee J, Lim S, Lee K, Guo X, Kamath R, Yamato H, et al. Secondhand smoke exposures in indoor public places in seven Asian countries. Int J Hyg Environ Health. 2010;213(5):348-51.

14. Kim S, Sohn J, Lee K. Exposure to particulate matters (PM2.5) and airborne nicotine in computer game rooms after implementation of smoke-free legislation in South Korea. Nicotine Tob Res. 2010;12(12):1246-53

15. Navas-Acien A, Peruga A, Breysse P, Zavaleta A, BlancoMarquizo A, Pitarque R, et al. Secondhand tobacco smoke in public places in Latin America, 2002-2003. JAMA. 2004;291(22):2741-5.

16. Hammond SK, Leaderer BP. A diffusion monitor to measure exposure to passive smoking. Environ Sci Technol. 1987;21:494-7.

17. Avila-Tang E, Travers MJ, Navas-Acien A. Promoting smoke-free environments in Latin America: a comparison of methods to assess secondhand smoke exposure. Salud Publica Mex. 2010;52 Suppl 2:S138-48.

18. Hornung R, Reed L. Estimation of average concentration in the presence of nondetectable values. Appl Occup Environ Hyg. 1990(5):46-51.

19. Stillman F, Navas-Acien A, Ma J, Ma S, Avila-Tang E, Breysse $\mathrm{P}$, et al. Second-hand tobacco smoke in public places in urban and rural China. Tob Control. 2007;16(4):229-34.

20. WHO [Internet]. WHO air quality guidelines for particulate matter, ozone, nitrogen dioxide, and sulfur dioxide: Summary of risk assessment. Geneva: World Health Organization; 2006; Available from: whqlibdoc.who.int/ hq/2006/WHO_SDE_PHE_OEH_06.02_eng.pdf. 